\title{
IMPLEMENTASI PENILAIAN AUTENTIK OLEH GURU BAHASA JEPANG DI KELAS X SMA LABORATORIUM UNDIKSHA SINGARAJA
}

\author{
K.A.K.Dewi ${ }^{1}$, K.E.K.Adnyani ${ }^{2}$, D.M.S.Mardani ${ }^{3}$ \\ ${ }^{123}$ Program Studi Pendidikan Bahasa Jepang, Jurusan Bahasa Asing, \\ Fakultas Bahasa dan Seni \\ Universitas Pendidikan Ganesha \\ Singaraja, Indonesia \\ e-mail: ayu.kharisma.dewi@undiksha.ac.id, krishna.adnyani@undiksha.ac.id, \\ desak.mardani@undiksha.ac.id
}

\begin{abstract}
Abstrak
Penelitian ini bertujuan untuk menganalisis (1) perencanaan penilaian autentik, (2) pelaksanaan penilaian autentik, dan (3) hambatan yang dialami oleh guru bahasa Jepang dalam pelaksanaan penilaian autentik di kelas X SMA Laboratorium Undiksha Singaraja. Metode pengumpulan data yang digunakan dalam penelitian ini adalah observasi, wawancara, dan studi dokumen. Data dianalisis dengan menggunakan analisis kualitatif. Subjek yang digunakan dalam penelitian ini adalah guru bahasa Jepang di SMA Laboratorium Undiksha Singaraja. Objek penelitian ini adalah perencanaan penilaian autentik, pelaksanaan penilaian autentik, dan hambatan yang dihadapi oleh guru bahasa Jepang di kelas X SMA Laboratorium dalam pelaksanaan penilaian autentik. Hasil penelitian menunjukkan bahwa (1) perencanaan penilaian yang dibuat oleh guru bahasa Jepang di kelas X SMA Laboratorium Undiksha Singaraja sudah menggunakan penilaian autentik, (2) pelaksanaan penilaian autentik sudah berjalan dengan baik sesuai dengan yang dirancang dalam RPP yakni penilaian aspek kompetensi pengetahuan menggunakan teknik tes tulis, tes lisan, dan penugasan. Sedangkan penilaian aspek kompetensi keterampilan siswa menggunakan teknik unjuk kerja/performance, (3) hambatan yang dihadapi guru dalam pelaksanaan penilaian autentik adalah kurangnya alokasi waktu untuk melakukan penilaian dan kebingungan dalam memilih instrumen dan jenis penilaian.
\end{abstract}

Kata kunci : bahasa Jepang, pembelajaran, penilaian autentik

\footnotetext{
要旨

本研究の目的なは、シンガラジャウンディクシャラボラトリウム の高校一年生において (1) 絶対評価計画、(2) 絶対評価実施、(3) 絶対評価実施の障害を分析し、明らかにすることである。調査 方法は観察、インタビュー、及び書類研究である。収集したデータは定性的法により分析した。調査 対象はにシンガラジャウンディクシャラボラトリウムの一年生日本語の教師による実施した、絶対評 価の計画、絶対評価の実施、絶対評価の障害である。分析した結果は、(1)シンガラジャウンディク シャラボラトリウム高校一年生の評価計画には絶対評価を設計したの使用における。(2) 絶対評価実 施は学習実施計画で設計されたものに従っている。知識の評価が口頭テスト、課題及び、書き込みテ ストより評価され、能力の評価がperformanceより評価された。(3) 絶対評価実施の障害は時間が限ら れである評価ほうほやの種類を選ぶのが混乱とういてことである。 キーワード:日本語、授業、絶対評価
} 


\section{Pendahuluan}

Komponen yang paling penting dalam dunia pendidikan adalah kurikulum. Menurut Hamalik (2012:18) kurikulum adalah seperangkat rencana dan pengaturan mengenai isi dan bahan pelajaran serta cara yang digunakan sebagai pedoman penyelenggaraan kegiatan belajar mengajar di dalam kelas. Kurikulum dijadikan sebagai sebuah wadah yang akan menentukan arah pendidikan sehingga berhasil atau tidaknya sebuah pendidikan sangat bergantung pada kurikulum yang digunakan. Pada Tahun Ajaran 2013/2014, Indonesia menerapkan kurikulum baru yang dikenal dengan sebutan kurikulum 2013.

Kurikulum 2013 menitikberatkan pada tiga kompetensi yakni kompetensi sikap, kompetensi pengetahuan, dan kompetensi keterampilan secara proporsional. Kurikulum 2013 digunakan sebagai upaya meningkatkan kualitas pendidikan pada generasi muda agar mampu menghadapi perubahan ilmu pengetahuan dan teknologi (IPTEK). Prinsip yang paling mendasar dalam kurikulum 2013 adalah kemampuan guru yang dituntut mampu mengimplementasikan proses pembelajaran yang autentik, menantang dan bermakna bagi peserta didik sehingga dengan demikian potensi peserta didik dapat berkembang sesuai dengan tujuan pembelajaran. Jadi, kurikulum 2013 dapat terlaksana dengan baik apabila guru yang memegang peranan penting dalam pelaksanaan kurikulum memahami secara menyeluruh kurikulum 2013.

Tahun Ajaran 2016/2017 kurikulum 2013 diberlakukan secara Nasional yang disebut dengan kurikulum 2013 edisi revisi. Pemerintah melalui Kementerian Pendidikan dan Kebudayaan (Kemendikbud, 2016) melakukan beberapa perbaikan terkait dengan kurikulum 2013 edisi revisi antara lain (1) penataan kompetensi spiritual dan sikap sosial pada semua mata pelajaran. Pada kurikulum 2013 edisi revisi penilaian untuk kompetensi sikap dan spiritual hanya dilakukan oleh guru mata pelajaran agama, PPKN, dan budi pekerti secara langsung dan tidak langsung dalam pembelajaran. Sedangkan untuk guru diluar mata pelajaran tersebut menilai kompetensi sikap dan spiritual secara tidak langsung dalam pembelajaran. (2) pemberian ruang kreatif kepada guru dalam mengimplementasi kurikulum. Dalam kurikulum 2013 edisi revisi, pendekatan saintifik bukan satu-satunya pendekatan yang digunakan. Guru dapat mengembangkan kemampuan dan kreativitasnya dalam pembelajaran sesuai dengan karakteristik siswa, kompetensi yang ingin dicapai, materi pelajaran, dan kondisi masing-masing sekolah. (3) penataan kompetensi yang tidak dibatasi oleh pemenggalan taksonomi proses berpikir. Pada kurikulum 2013 edisi revisi, kemampuan berpikir tingkat tinggi sudah diberikan kepada siswa jenjang sekolah dasar sampai menengah yang disesuaikan dengan usia peserta didik. (4) sistem satuan penilaian yang digunakan. Pada kurikulum 2013 edisi revisi skala penilaian menggunakan angka 1-100.

Dengan adanya kurikulum 2013 edisi revisi, terjadi perubahan signifikan pada sistem penilaian yang digunakan. Penilaian merupakan salah satu bagian terpenting dalam sistem pendidikan yang digunakan untuk meningkatkan kualitas pembelajaran. Penilaian yang digunakan pada kurikulum 2013 adalah penilaian autentik (authentic assesment). Dalam penilaian autentik terdapat 2 sasaran pokok yaitu proses pembelajaran dan hasil pembelajaran (Muslich, 2011). Oleh sebab itu penilaian tidak hanya bertujuan untuk mengetahui hasil belajar siswa, tetapi melalui penilaian guru juga mengetahui bagaimana proses belajar siswa tersebut berlangsung.

Penilaian autentik sangat berbeda dengan penilaian konvensional yang digunakan pada kurikulum KTSP (Kurikulum Tingkat Satuan Pendidikan). Pada penilaian autentik lebih menekankan pada aspek kognitif, afektif, dan psikomotor sedangkan pada kurikulum KTSP (Kurikulum Tingkat Satuan Pendidikan) lebih menekankan pada aspek kognitif saja. Penilaian autentik sangat cocok diterapkan untuk menilai keterampilan berbahasa peserta didik. Sesuai dengan pendapat Nurgiyantoro (2011), penilaian autentik dapat diterapkan untuk menilai keempat aspek keterampilan berbahasa, yaitu berbicara, membaca, menulis dan menyimak. Sebagai salah satu bahasa asing yang diperoleh pada jenjang pendidikan menengah atas, bahasa Jepang merupakan mata pelajaran yang dianggap penting untuk dipelajari. Hal tersebut dibuktikan dengan kebijakan pemerintah memasukan mata pelajaran bahasa Jepang sebagai ilmu peminatan yang diatur dalam Permendikbud No. 69 Tahun 
2013 tentang Kerangka Dasar dan Struktur Kurikulum Sekolah Menengah Atas/Madrasah Aliyah.

SMA Laboratorium Undiksha Singaraja adalah salah satu sekolah menengah atas yang memberikan mata pelajaran bahasa Jepang dalam pembelajarannya. SMA Laboratorium Undiksha Singaraja baru menerapkan kurikulum 2013 pada Tahun Ajaran 2018/2019 dan menggunakan penilaian autentik dalam proses penilaiannya. SMA Laboratorium Undiksha Singaraja adalah satu-satunya sekolah swasta di bawah naungan Universitas Pendidikan Ganesha yang merupakan perguruan tinggi negeri terbaik di Bali Utara. Sebagai sekolah naungan dari Universitas Pendidikan Ganesha seharusnya guru dalam mengimplementasikan kurikulum 2013 beserta proses penilaian tidak mengalami kesulitan. Namun hal tersebut sangat berbanding terbalik dengan kenyataan yang ditemukan di lapangan.

Berdasarkan hasil wawancara terhadap guru bahasa Jepang di SMA Laboratorium Undiksha Singaraja pada tanggal 19 Februari 2019 diperoleh informasi bahwa di SMA Laboratorium Undiksha Singaraja, hanya kelas X yang sudah menggunakan kurikulum 2013 sedangkan kelas XI dan XII masih menggunakan kurikulum KTSP. Selanjutnya mengenai penilaian autentik, guru mengalami kebingungan dalam menerapkannya pada pembelajaran di kelas. Hal tersebut dikarenakan guru bahasa Jepang disekolah tersebut untuk pertama kalinya menggunakan penilaian autentik. Banyak hal yang harus dipersiapkan guru sebelum melakukan penilaian salah satunya menyiapkan instrumen penilaian yang memuat ketiga kompetensi yang akan dinilai. Dalam proses penilaian guru mengalami kebingungan karena harus mengkaitkan kompetensi sikap, keterampilan, dan pengetahuan dengan kehidupan nyata peserta didik. Oleh sebab itu, perlu adanya penelitian mengenai penilaian autentik untuk dapat mengetahui bagaimana guru bahasa Jepang di SMA Laboratorium Undiksha Singaraja dalam mengimplementasikan penilaian autentik.

Penelitian sejenis pernah dilakukan oleh Pitriani (2018). Penelitian ini menggunakan rancangan deskriptif kualitatif dengan subjek penelitian yaitu guru bahasa Jepang di kelas IX SMA Negeri 4 Singaraja. Hasil penelitian menunjukkan bahwa perencanaan yang dibuat oleh guru mata pelajaran bahasa Jepang di Kelas XI SMA Negeri 4 Singaraja sudah menggunakan penilaian autentik dan memperoleh nilai 81,25 dengan kategori baik. Pelaksanaan penilaian autentik sudah berjalan dengan baik yakni pada kelas XI BB 1 memperoleh nilai 76,18 dan kelas XI BB 2 memperoleh nilai 76,18. Penilaian sikap menggunakan teknik observasi dan jurnal. Penilaian pengetahuan menggunakan teknik tes tulis, tes lisan, dan penugasan. Penilaian keterampilan menggunakan unjuk kerja/performance dan portopolio. Dalam menggunakan penilaian autentik guru terdapat kendala yang dihadapi oleh guru bahasa Jepang yaitu banyaknya hal yang harus dinilai namun waktu terbatas dan sarana sekolah yang kurang memadai.

Berdasarkan latar belakang yang telah dipaparkan diatas, dapat ditarik rumusan masalah penelitian sebagai berikut. 1) Bagaimanakah perencanaan penilaian autentik oleh guru bahasa Jepang di kelas X SMA Laboratorium Undiksha Singaraja? 2) Bagaimanakah pelaksanaan penilaian autentik oleh guru bahasa Jepang di kelas X SMA Laboratorium Undiksha Singaraja, dan 3) Apa sajakah hambatan yang dihadapi oleh guru bahasa Jepang dalam pelaksanaan penilaian autentik di kelas X SMA Laboratorium Undiksha Singaraja?

\section{Metode \\ Metode Pengumpulan Data}

Penelitian ini dilaksanakan di SMA Laboratorium Undiksha Singaraja. Subjek yang digunakan pada penelitian ini adalah guru bahasa Jepang di SMA Laboratorium Undiksha Singaraja. Sedangkan objek pada penelitian ini adalah penilaian autentik yang meliputi perencanaan penilaian autentik, pelaksanaan penilaian autentik, dan hambatan yang dialami oleh guru dalam pelaksanaan penilaian autentik.

Penelitian ini merupakan penelitian studi kasus dengan rancangan pendekatan kualitatif. Penelitian studi kasus (case study) adalah suatu penelitian yang berusaha menentukan makna, menyelidiki proses, dan memperoleh pengertian, dan pemahaman yang mendalam dari individu, kelompok, atau situasi (Emzir, 2010). Terdapat 3 metode pengumpulan data yang digunakan dalam penelitan ini yaitu observasi, wawancara, dan studi dokumen. Data 
yang telah dikumpulkan di analisis menggunakan pendekatan deskriptif kualitatif. Metode dan teknik analisis data yang digunakan yaitu reduksi data, penyajian data (display), dan penarikan kesimpulan atau verifikasi. Selanjutnya untuk mengecek keabsahan data, dalam penelitian ini menggunakan 2 teknik triangulasi yaitu triangulasi sumber data dan triangulasi teori.

\section{Hasil dan Pembahasan}

Sesuai dengan rumusan masalah yang dikaji, hasil penelitian ini meliputi(1) perencanaan penilaian autentik, (2) pelaksanaan penilaian autentik, dan (3) hambatan yang dihadapi oleh guru bahasa Jepang dalam pelaksanaan penilaian autentik. Hasil penelitian akan dipaparkan sebagai berikut.

\section{Perencanaan Penilaian Autentik}

Penilaian autentik merupakan penilaian yang digunakan pada kurikulum 2013 edisi revisi. Penilaian autentik adalah penilaian yang lebih menekankan pada aspek kompetensi sikap, kompetensi pengetahuan, dan kompetensi keterampilan secara komprehensif untuk menilai dari masukan, proses, dan hasil pembelajaran. Penggunaan penilaian autentik dalam kegiatan pembelajaran, menuntut siswa menerapkan konsep atau teori ke dalam kehidupan sehari-hari. Namun dengan adanya kurikulum 2013 edisi revisi, sedikit mempermudahkan kinerja guru terutama guru mata pelajaran bahasa Jepang. Hal tersebut disebabkan tidak semua guru mata pelajaran melakukan penilaian aspek kompetensi sikap secara langsung dalam pembelajaran. Hanya guru mata pelajaran PPKN, agama, dan budi pekerti yang melakukan penilaian secara langsung sedangkan guru di luar mata pelajaran tersebut melakukan penilaian aspek kompetensi sikap secara tidak langsung. Untuk mengetahui dan menganalis perencanaan penilaian autentik di kelas X SMA Laboratorium Undiksha Singaraja, dilakukan pengambilan data dengan menggunakan teknik analisis studi dokumen. Dokumen yang dianalisis berupa 5 RPP.

Sebelum melakukan penilaian di dalam kelas, hal terpenting yang harus dilakukan oleh seorang guru adalah membuat atau menyiapkan perencanaan penilaian sesuai dengan silabus yang dimasukkan ke dalam RPP. Hal tersebut sesuai dengan pernyataan dari Kunandar (2011:263) bahwa RPP adalah rencana yang menggambarkan prosedur dan pengorganisasian pembelajaran untuk mencapai satu kompetensi dasar yang ditetapkan dalam standar isi dan dijabarkan dalam silabus. Oleh sebab itu, perencanaan penilaian harus disesuaikan dengan penilaian yang tercantum dalam silabus. Hal tersebut juga tercantum dalam Permendikbud No. 23 Tahun 2016 yang berbunyi "perancangan strategi penilaian oleh pendidik dilakukan pada saat penyusunan rencana pelaksanaan pembelajaran (RPP) berdasarkan silabus".

Sebelum guru bahasa Jepang di SMA Laboratorium Undiksha Singaraja melakukan penilaian autentik dalam pembelajaran, terlebih dahulu guru menyusun instrumen penilaian dalam RPP yang disesuaikan dengan silabus dan materi yang dipelajari. Teknik penilaian yang tercantum dalam silabus adalah observasi, tes tulis, tes lisan, penugasan, unjuk kerja, dan portofolio. Namun dalam RPP guru tidak mencantumkan teknik penilaian menggunakan tes lisan dan portofolio. Dalam RPP guru merancang penilaian aspek kompetensi pengetahuan dengan menggunakan teknik tes tulis dan penugasan serta dilengkapi dengan instrumen penilaian berupa teknik penilaian, rubrik penilaian dan pedoman penskoran. Sedangkan untuk aspek kompetensi keterampilan dalam RPP guru merancang menggunakan teknik unjuk kinerja/performance yang sudah dilengkapi dengan instrumen penilaian berupa rubrik penilaian, rentangan skor, dan pedoman penskoran.

Penilaiann aspek kompetensi pengetahuan, guru merancangan teknik penilaian dengan menggunakan teknik tes tulis dan penugasan. Teknik tes tulis dirancang guru pada kelima RPP, sedangkan penugasan dirancang guru pada RPP I, IV, dan V. Jenis tes tulis yang dirancang oleh guru dalam RPP I, II, dan V sama yakni memberikan 2 jenis soal antara lain mengubah kosakata bahasa Jepang ke dalam bahasa Indonesia dan menyalin kosakata 
bahasa Jepang ke dalam huruf hiragana dan katakana. Pada RPP III, tes tulis yang dirancang guru menggunakan 2 jenis soal yaitu mengubah kosakata bahasa Indonesia ke dalam bahasa Jepang dan membuat 2 kalimat sesuai dengan pola kalimat " KB (Keterangan Waktu)に KB (Seragam Sekolah) をきます”. Sedangkan pada RPP IV, guru menggunakan 3 jenis soal yaitu mengubah kosakata bahasa Indonesia ke dalam bahasa Jepang, membuat kalimat dengan pola kalimat “ KB (Kegiatan) は(waktu) でした”, dan menyusun kalimat acar agar menjadi kalimat yang benar sesuai pola kalimat yang dipelajari.

Selain teknik tes tulis, guru menggunakan teknik penugasan untuk menilai aspek kompetensi siswa yang hanya terdapat pada RPP I, IV, dan V. Pada RPP I, teknik penugasan yang diberikan yaitu membuat karangan mengenai sifat guru di sekolah. Sedangkan pada RPP IV dan V, siswa diminta untuk membuat laporan hasil wawancara. Pada RPP IV, siswa diminta untuk membuat laporan hasil wawancara terhadap 3 orang teman yang berbeda kelas, sedangkan pada RPP V, siswa diminta membuat hasil laporan mengenai "dengan siapa, di mana, dan apa yang dimakan saat makan siang di sekolah. Tugas tersebut diberikan waktu untuk pengerjakan selama 1 minggu dan dikumpulkan pada saat pertemuan selanjutnya. Hal tersebut sesuai dengan pendapat Kunandar (2015), penugasan dapat berupa pekerjaan rumah yang dapat dikerjakan individual maupun kelompok sesuai karakteristik tugas dengan alokasi waktu tertentu. Jadi, dengan perencanaan penilaian dengan menggunakan teknik tes tulis dan penugasan, siswa akan mampu mengingat dan memahami kosakata serta pola kalimat yang dipelajari.

Teknik yang digunakan untuk menilai aspek kompetensi pengetahuan siswa tersebut sesuai dengan pendapat Kunandar (2015:165) bahwa cara yang dapat digunakan untuk menilai aspek kompetensi pengetahuan siswa antara lain melalui tes tertulis, tanya jawab (tes lisan), dan penugasan. Hal tersebut juga tercantum dalam Permendikbud No. 23 Tahun 2016 pasal 9 ayat 3 yang berbunyi "penilaian aspek pengetahuan dilakukan melalui tes tulis, tes lisan, dan penugasan dengan kompetensi yang dinilai".

Dalam menyusun perencanaan penilaian aspek kompetensi keterampilan siswa, guru menggunakan unjuk kerja/performance dalam RPP I sampai V. Perencanaan penilaian aspek kompetensi keterampilan yang disusun oleh guru dalam RPP telah dilengkapi instrumen penilaian berupa rubrik penilaian dan rentangan skor sehingga memudahkan guru melakukan penilaian. Pada RPP I sampai V, guru telah merancangan penilaian aspek kompetensi keterampilan dengan mengacu pada kriteria tertentu yaitu kelancaran, kosakata, tata bahasa, dan pelafalan. Namun, pada RPP I sampai V terdapat kesalahan pada indikator pencapaian kompetensi (IPK). Dalam IPK, guru meminta siswa membuat percakapan sedangkan dalam unjuk kerja/performance siswa seharusnya melakukan percakapan bukan membuat percakapan.

Untuk memperoleh nilai akhir siswa guru melakukannya dengan cara jumlah perolehan skor siswa dibagi dengan jumlah skor maksimal kemudian di kali 100. Unjuk kerja/performance yang digunakan adalah melakukan percakapan (roleplay) di depan kelas sesuai dengan materi yang dipelajari. Penilaian aspek kompetensi keterampilan dengan menggunakan teknik unjuk kerja/performance sesuai dengan yang tercantum dalam Permendikbud No. 23 Tahun 2016 pasal 9 ayat 4 yang berbunyi "penilaian keterampilan dilakukan melalui praktik, produk, proyek, portofolio, dan/atau teknik lain sesuai dengan kompetensi yang dinilai".

Dalam RPP, guru bahasa Jepang telah mencantumkan tindak lanjut hasil pembelajaran. Hal tersebut sangat penting dilakukan untuk memperbaiki proses pembelajaran yang rancang dalam RPP. Tindak lanjut yang direncanakan oleh guru yaitu program pengayaan (enrichment) dan perbaikan (remidial). Sesuai dengan pendapat dari Suyono dan Hariyanto (2015:247), salah satu yang perlu diperhatikan dalam melakukan penilaian adalah menentukan tindak lanjut berupa program remedi bagi peserta didik yang pencapaian kompetensinya di bawah kriteria ketuntasan minimal (KKM), dan program pengayaan bagi peserta didik yang telah mencapai KKM. Dengan adanya kegiatan tersebut, akan mampu menunjukkan kekurangan guru dalam pembelajaran sehingga memberikan kesempatan guru untuk memperbaiki proses pembelajaran. 


\section{Pelaksanaan Penilaian Autentik}

Pelaksanaan penilaian autentik dalam pembelajaran, seharusnya disesuaikan dengan rancangan penilaian yang terdapat pada RPP. Hal tersebut dikarenakan hasil penilaian autentik akan dijadikan sebagai feedback atau umpan balik dalam pembelajaran. Sehingga melalui hasil penilaian guru mengetahui kekurangan dalam kegiatan pembelajaran dan merancang kembali kegiatan pembelajaran agar lebih baik.

Sesuai dengan salah satu fungsi penilaian autentik yaitu fungsi formatif yang berarti melalui penilaian diperoleh infomasi berupa umpan balik (feedback), baik bagi guru maupun bagi siswa selama pembelajaran berlangsung (Jihad \& Abdul, 2012). Hal ini diperkuat dengan pendapat yang dikemukakan oleh Kunandar (2015) bahwa penilaian autentik dapat digunakan sebagai feedback, artinya penilaian autentik dilakukan oleh guru sebagai umpan balik terhadap pencapaian kompetensi peserta didik secara komprehensif. Jadi, dengan adanya penilaian seorang guru mampu mengetahui kekurangan dalam proses pembelajaran sehingga mampu melakukan perbaikan-perbaikan dalam pembelajaran dan tujuan pembelajaran dapat tercapai.

Dalam pelaksanaan penilaian autentik, guru bahasa Jepang kelas $X$ di SMA Laboratorium Undiksha Singaraja mengimplementasikan penilaian autentik sesuai dengan apa yang dirancang dalam RPP. Sesuai dengan pernyataan yang terdapat pada Permendikbud No. 23 Tahun 2016 yang menyatakan bahwa pendidik dalam melakukan kegiatan penilaian dalam pembelajaran harus sesuai dengan rencana penilaian yang telah disusun diawal kegiatan pembelajaran.

Dalam kegiatan pembelajaran di kelas, sangat penting bagi seorang guru untuk memberikan informasi mengenai sistem penilaian kepada siswa. Hal tersebut sudah dilakukan oleh guru bahasa Jepang di kelas X SMA Laboratorium Undiksha Singaraja. Guru menyampaikan sistem penilaian kepada siswa sebelum siswa mengerjakan tugas dan mempresentasikan tugasnya di depan kelas. Guru berpedoman pada rubrik penilaian yang sudah dicantumkan dalam rencana kegiatan pembelajaran (RPP). Sehingga saat pembelajaran berlangsung guru menyebutkan hal-hal apa saja yang akan dinilai pada tugas siswa.

Penyampaian sistem penilaian yang dilakukan oleh guru tersebut memiliki manfaat bagi pendidik maupun bagi peserta didik. Menurut Ediawati, dkk (2016) bagi pendidik manfaat penyampaian sistem penilaian yaitu pendidik akan lebih mudah menilai peserta didik karena yang lebih ditonjolkan oleh peserta didik adalah hal-hal yang masuk dalam penilaian. Sementara bagi peserta didik, dengan penyampaian penilaian tersebut dapat lebih mempersiapkan diri untuk menunjukkan kemampuannya secara maksimal sesuai dengan yang diharapkan oleh pendidik.

Pada pelaksanaaan penilaian aspek kompetensi pengetahuan, guru bahasa Jepang di SMA Laboratorium Undiksha Singaraja menggunakan teknik tes tulis, tes lisan, dan penugasan yang sudah sesuai dengan Permendikbud No. 23 Tahun 2016 pasal 9 ayat 1 yang berbunyi "penilaian aspek pengetahuan dilakukan melalui tes tertulis, tes lisan, dan penugasan sesuai dengan kompetensi yang dinilai". Teknik penilaian yang dilakukan oleh guru dalam pelaksanaan pembelajaran berbeda dengan perencanaan yang telah disusun oleh guru pada 5 RPP yang telah dianalisis. Di dalam RPP, guru hanya mencantumkan penilaian dengan teknik tes tulis dan penugasan sedangkan penilaian dengan teknik tes lisan tidak dicantumkan. Penilaian dengan menggunakan teknik tes lisan dilakukan oleh guru secara spontan tanpa adanya perencanaan, instrumen maupun rubrik penilaian yang dimasukkan ke dalam RPP.

Berdasarkan wawancara yang dilakukan, alasan guru tidak mencantumkan penilaian aspek kompetensi pengetahuan dengan teknik tes lisan dalam RPP karena guru menganggap bahwa penilaian aspek kompetensi pengetahuan cukup menggunakan tes tulis dan penugasan. Selain itu guru juga kebingungan untuk membuat instrumen penilaian tes lisan. Sehingga guru melakukan penilaian dengan teknik tes lisan secara spontan dan disesuaikan dengan materi yang dipelajari. Nilai yang diperoleh siswa melalui teknik tes lisan dijadikan sebagai nilai tambahan berupa poin untuk membantu nilai siswa sehingga mampu memperoleh nilai di atas KKM. 
Dalam pelaksanaan penilaian aspek pengetahuan guru juga menggunakan teknik penugasan yang dilakukan dengan memberikan tugas kepada siswa. Guru memberikan teknik penugasan kepada siswa hanya pada observasi pertama dan keempat. Pada observasi pertama, siswa diminta menulis karangan mengenai sifat guru mata pelajaran di sekolah dan pada observasi keempat, siswa ditugaskan untuk membuat laporan hasil interview terhadap 3 orang teman dengan situasi berbeda kelas yang sesuai dengan materi yang pelajari. Tugas tersebut dikerjakan dalam waktu satu minggu dan dikumpul pada saat pertemuan selanjutnya. Hal ini sejalan dengan pendapat Kunandar (2015:40), penugasan adalah tugas yang diberikan oleh guru kepada peserta didik dalam waktu tertentu sebagai implementasi dan pendalaman dari pengetahuan yang diperoleh dalam pembelajaran.

Dalam pelaksanaan pembelajaran saat ini yang menggunakan kurikulum 2013 edisi revisi, siswa tidak hanya dituntut penguasaan terhadap aspek pengetahuan saja, siswa juga dituntut untuk mampu mengimplementasikan pengetahuan yang dimiliki. Hal tersebut sesuai dengan pendapat Fadillah (2014:16), bahwa kurikulum 2013 menekankan pada peningkatan dan pengembangan soft skill dan hard skill.

Penilaian aspek kompetensi keterampilan dilakukan oleh guru bahasa Jepang kelas $X$ di SMA Laboratorium Undiksha Singaraja dengan menggunakan teknik unjuk kerja/performance. Teknik penilaian unjuk kerja/performance sesuai dengan rancangan penilaian pada RPP. Pada observasi pertama sampai keempat guru meminta siswa membuat percakapan dan secara berpasang-pasangan melakukan percakapan (roleplay) di depan kelas. Pada saat penilaian tersebut, siswa akan menunjukkan keterampilannya dalam menggunakan bahasa Jepang.

Pada kegiatan pembelajaran di kelas, guru bahasa Jepang di kelas X SMA Laboratorium Undiksha Singaraja selalu memberikan soal dan tugas yang berkaitan dengan kehidupan sehari-hari seperti contohnya memberikan tugas mengenai letak benda yang ada di dalam kelas Hal tersebut bertujuan agar siswa mampu menerapkan konsep atau teori yang diperoleh kedalam kehidupan nyata sehari-hari. Hal tersebut sesuai dengan yang disampaikan oleh Kunandar (2015:38) bahwa salah satu ciri-ciri dari penilaian autentik adalah tugas-tugas yang diberikan kepada peserta didik harus mencerminkan bagian-bagian kehidupan peserta didik yang nyata setiap hari, mereka harus dapat menceritakan pengalamannya.

Selain itu, guru juga melakukan penilaian selama proses pembelajaran berlangsung. Penilaian proses dalam pembelajaran terlihat ketika guru mengamati bagaimana siswa mengerjakan tugas yang diberikan, memberikan siswa kesempatan untuk berlatih tanya jawab dengan temannya, melihat keaktifan dan aktivitas siswa dalam mengikuti pembelajaran. Sesuai dengan pendapat Mulyasa (2017), bahwa penilaian proses pembelajaran yaitu penilaian terhadap aktivitas, keaktifan, dan sikap peserta didik saat mengikuti pelajaran. Dalam penilaian proses, guru bahasa Jepang di SMA Laboratorium Undiksha Singaraja melihat perkembangan siswa dari yang tidak bisa menjadi bisa, melihat keaktifan dan antusiasme siswa dalam mengikuti pembelajaran.

Dengan adanya penilaian proses dalam pembelajaran, guru tidak hanya melihat hasil akhirnya saja tetapi melihat dari proses siswa mengikuti pembelajaran di kelas. Hal tersebut diperkuat dengan pendapat Muslich (2011:2) bahwa penilaian autentik tidak hanya mengtehui hasil berlajar peserta didik, tetapi juga untuk mengetahui proses belajar tersebut berlangsung.

Berdasarkan dari hasil belajar siswa, perlu adanya tindak lanjut yang harus dilakukan guru untuk meningkatkan kualitas pembelajaran. Tindak lanjut yang dilakukan berupa perbaikan (remidial). Hal ini telah dilakukan juga oleh guru bahasa Jepang kelas $X$ di SMA Laboratorium Undiksha Singaraja. Perbaikan (remidial) diberikan kepada siswa yang belum mencapai nilai KKM yaitu berupa beberapa pertanyaan-pertanyaan yang membuat siswa lebih memahami materi yang diajarkan. Soal yang diberikan yaitu mengubah kosakata dari bahasa indonesia ke dalam bahasa Jepang dan menerjemahkan kalimat bahasa Jepang ke dalam bahasa Indonesia. Hal tersebut sesuai dengan Permendikbud No. 23 Tahun 2016 Bab IV pasal 9 ayat 5 yang berbunyi "peserta didik yang belum mencapai KKM satuan pendidikan harus mengikuti pembelajaran remidi”. 
Dengan demikian, guru bahasa Jepang di SMA Laboratorium Undiksha Singaraja sudah mampu melaksanakan penilaian autentik dalam pembelajaran sesuai dengan perencanaan penilaian yang terdapat dalam RPP. SMA Laboratorium Undiksha Singaraja merupakan salah satu sekolah yang baru menerapkan kurikulum 2013 dalam pembelajaran, namun guru sudah mampu melakukan penilaian autentik sesuai dengan tuntutan dalam kurikulum 2013 edisi revisi. Selain itu, terdapat teknik penilaian yang tidak tercantum dalam RPP, namun guru sudah melakukan penilaian aspek kompetensi pengetahuan dan kompetensi keterampilan dengan menggunakan teknik yang tepat.

\section{Hambatan yang dialami oleh Guru Bahasa Jepang dalam Pelaksanaan Penilaian Autentik}

Hambatan yang dialami oleh guru bahasa Jepang dalam pelaksanaan penilaian autentik antara lain kurangnya alokasi waktu mata pelajaran bahasa Jepang. Dalam kurikulum 2013 edisi revisi, penilaian kompetensi pengetahuan dan kompetensi keterampilan harus dilakukan dalam setiap pembelajarannya. Guru merasa penilaian autentik sulit dilakukan dengan alokasi waktu yang terbatas. Dengan waktu yang terbatas, guru kurang maksimal dalam melakukan kegiatan pembelajaran dan penilaian autentik yang dituntut dalam kurikulum 2013 edisi revisi. Sehingga guru mencari solusi guru untuk mengatasi hambatan tersebut yaitu dengan cara hanya menggunakan beberapa teknik penilaian sesuai dengan kompetensi yang akan dinilai. Hal tersebut bertujuan untuk mengefisienkan waktu dan dapat melakukan pembelajaran serta penilaian dengan maksimal.

Hambatan kedua yaitu guru mengalami kebingungan ketika memilih instrumen dan jenis penilaian. Dalam kurikulum 2013 edisi revisi, guru dituntut untuk melakukan penilaian dengan menggunakan jenis penilaian yang bervariasi sehingga penilaian yang dilakukan oleh guru tidak monoton. Sesuai dengan pendapat dari Majid (2014:90), dalam melakukan penilaian autentik guru harus menggunakan instrumen yang bervariasi (tidak hanya satu instrumen). Solusi guru untuk mengatasi hambatan tersebut yaitu guru lebih banyak membaca dari berbagai sumber mengenai penilaian autentik dan bertanya serta bertukar pikiran dengan rekan kerja.

\section{Simpulan dan Saran}

Berdasarkan analisis terhadap data hasil penelitian, dapat ditarik kesimpulan antara lain:

1. Dalam penelitian ini dianalisis perencanaan penilaian autentik oleh guru bahasa Jepang di kelas X SMA Laboratorium Undiksha Singaraja. Pada aspek kompetensi pengetahuan guru merancang penilaian dalam RPP yakni menggunakan teknik tes tulis dan penugasan. Untuk aspek kompetensi keterampilan guru menggunakan penilaian unjuk kerja/performance.

2. Dalam pelaksanaannya, guru bahasa Jepang kelas $X$ di SMA Laboratorium Undiksha Singaraja sudah melakukan penilaian autentik sesuai dengan tuntutan kurikulum 2013 edisi revisi. Pelaksanaan penilaian untuk aspek kompetensi pengetahuan menggunakan teknik tes tulis, tes lisan, dan penugasan. Penilaian aspek kompetensi keterampilan siswa menggunakan teknik unjuk kerja/performance.

3. Walaupun dalam perencanaan dan pelaksanaan penilaian autentik sudah dilakukan, namun masih terdapat hambatan yang dialami oleh guru bahasa Jepang dalam melaksanakan penilaian autentik yaitu kurangnya alokasi waktu untuk melakukan penilaian dan kesulitan dalam memilih instrumen dan jenis penilaian sesuai dengan materi pelajaran

Saran yang dapat disampaikan berdasarkan penelitian yang telah dilakukan adalah sebagai berikut.

1. Kepada guru. Walaupun dalam perencanaan dan pelaksanaan pembelajaran bahasa Jepang guru sudah menggunakan penilaian autentik, namun guru sebaiknya lebih memahami lagi mengenai kurikulum 2013 edisi revisi, terutama penilaian yang digunakan dalam kurikulum 2013 edisi revisi yakni penilaian autentik. Sehingga jenisjenis penilaian yang digunakan lebih beragam dan bervariasi. 
2. Kepada pihak sekolah. Disarankan kepada pihak sekolah untuk selalu tanggap terhadap pembaharuan-pembaharuan terkait kurikulum 2013 edisi revisi, sehingga dapat menunjang keberhasilan pelaksanaan kurikulum 2013 edisi revisi terutama dalam hal pelaksanaan penilaian autentik khususnya pada pembelajaran bahasa Jepang.

3. Kepada peneliti lain. Disarankan untuk melakukan penelitian sejenis yakni penilaian autentik berdasarkan kurikulum 2013 edisi revisi. Sebagai contoh melakukan penilaian pengembangan instrumen dalam penilaian autentik yang disesuaikan sesuai dengan kompetensi tertentu.

\section{Daftar Pustaka}

Hamalik, Oemar. 2012. Manajemen Pengembangan Kurikulum. Bandung: Remaja Rosdakarya.

Kemendikbud, 2016. "Media Komunikasi dan Inspirasi Jendela Pendidikan dan Kebudayaan Edisi III". Tersedia pada http://repositori.kemdikbud.go.id/3988/ (diakses tanggal 31 Januari 2019).

Kunandar. 2011. Langkah Mudah Penelitian Tindakan Kelas Sebagai Pengembangan Profesi Guru. Jakarta:Rajawali Pers.

Kunandar. 2015. Penilaian Autentik Suatu Pendekatan Praktis. PT Raja Gafindo Persada: Jakarta.

Jihad, Asep dan Abdul Haris. 2012. Evaluasi Pembelajaran. Yogyakarta: Multi Pressindo.

Majid, Abdul. 2014. Penilaian Autentik Proses dan Hasil Belajar. Bandung: PT Remaja Rosdakarya

Mulyasa, E. 2017. Pengembangan dan Implementasi Kurikulum 2013. Bandung: PT Remaja Rosdakarya Offset.

Muslich, Masnur. 2011. Authentic Assessment:Penilaian Berbasis Kelas dan Kompetensi. Bandung: PT Refika Aditama.

Nurgiantoro, Burhan. 2011. Penilaian Otentik Dalam Pembelajaran Bahasa. Yogyakarta: Gadjah Mada University Press.

Permendikbud. 2016. Peraturan Menteri Pendidikan dan Kebudayaan Republik Indonesia Nomor 23 Tahun 2016 tentang Standar Penilaian Pendidikan. Tersedia pada indonesia.org/.../Permendikbud Tahun2016 Nomor02...

Permendikbud. 2013. Peraturan Menteri Pendidikan dan Kebudayaan Republik Indonesia Nomor 69 Tahun 2013 tentang Kerangka Dasar dan Struktur Kurikulum Sekolah Menengah Atas/Madrasah Aliyah. Tersedia pada http://direktori.madrasah.kemenag.go.id/media/files/Permendikbud69TH201 3.pdf

Pitriani, Kadek, dkk. 2018. Penilaian Autentik oleh Guru Bahasa Jepang di Kelas XI SMA Negeri 4 Singaraja. Skripsi. Jurusan Pendidikan Bahasa Jepang. Fakultas Bahasa dan Seni. Universitas Pendidikan Ganesha. Tersedia pada https://ejournal.undiksha.ac.id/index.php/JJPBJ/article/view/14450

Suyono dan Hariyanto. 2015. Implementasi Belajar dan Pembelajaran. Bandung: PT Remaja Rosdakarya. 